UDC $338.22+338.054 .23$

JEL Classification: E6, E31, E32, P52

DOI: $10.15587 / 2706-5448.2021 .224661$

Article type «Original research»

\section{Oksana Okhrimenko, Oleksii Zrobok}

\title{
EVALUATION OF THE EFFECTIVENESS OF NATIONAL POLICIES OF MINIMIZATION OF CONSEOUENCES COVID-19 PANDEMICS
}

The object of research is the effectiveness of the implementation of measures within the national policy to minimize the effects of the COVID-19 pandemic in individual countries. One of the most problematic places is the formation of a policy to minimize the consequences of the COVID-19 pandemic, which would take into account the specifics of the national economy, its margin of safety and aimed at achieving the goals of stabilizing negative economic trends. The pandemic has led to forced quarantine restrictions, which have had a negative impact on national economies. The inability to set up full-fledged business processes has led to rising unemployment and social tensions.

An analysis of the main directions of the policy of minimizing the consequences of the pandemic of individual countries that made up the analytical sample. The main characteristics of the measures taken to minimize the effects of the pandemic, aimed at stabilizing the situation in the most crisis segments of the economy: financial assistance to small and medium-sized businesses, tax benefits, job creation and unemployment benefits, stabilization of the budget and banking system.

The study used a comparative analysis of the effectiveness of the pandemic confrontation through the prism of the adopted policy by analysing the dynamics of key macroeconomic indicators. This methodological approach involves the involvement of a large database, which presents the main macroeconomic indicators of individual countries and the study of the main parameters of national policies. This ensures that links are identified and that the results of the planned activities are compared. In comparison with known similar methods, this approach allows adding to the base of comparison global indices depending on the purpose of the study and to transform its subject.

In the applied aspect, the evaluation of the policy of confronting the pandemic will minimize the cost of time and resources to select and justify effective measures to minimize the negative consequences of unforeseen events and forecast economic trends.

Keywords: COVID-19 pandemic, national policy, minimization of negative consequences, macroeconomic indicators, expert forecasting.

\section{Introduction}

The COVID-19 pandemic has become a global challenge for the world economy and humanity at all. Forced quarantine measures led to the closure of enterprises, transport restrictions. As a result, rise in unemployment, decline in solvency of the population, the crisis of individual industries have thwarted the economic and social development plans of governments of many countries. It has forced governments to rethink the degree of risk and take anti-crisis measures. The economic recession that covered the world is often compared to the aftermath of World War II and the Great Depression of 1929-1933. All this requires government authorities and international organizations to take decisive and quick action to develop and implement a policy to minimize the negative impact of the COVID-19 pandemic on national economies. Their effectiveness depends on the availability of economic potential, the national policy of countering the pandemic and the speed of response to negative phenomena in the economy on the part of the executive branch. The problem of evaluating the effectiveness of national policies to counter and minimize the economic and social effects of COVID-19 is relevant and requires a comprehensive study.

\section{The object of research and its technological audit}

The object of research is the effectiveness of the implementation of measures within the national policy to minimize the effects of the Covid-19 pandemic in individual countries. Within this research, the policy is viewed as a tool and method that contributes to the achievement of targets in the process of confronting and overcoming the effects of the pandemic. The decision-making process at the state level, in the view of the global scale of the pandemic, is limited in time considering the dynamics of the spread of COVID-19 and the readiness of medical institutions to 
receive a significant number of patients. Each country has in its arsenal a set of tools and methods to minimize the effects of the pandemic and balance socio-economic growth. Given the almost equal experience in fighting against the pandemic, governments have gained experience which is manifested through a system of measures taken in different segments of public administration. At the same time, in the view of the unprecedented nature of voluntary restrictions on economic processes, the effectiveness of the implementation of national policies to counter and minimize the effects of the pandemic is insufficiently studied. Developments of a methodological and applied nature in this direction will make it possible to form algorithms for responding to pandemics in the future, which will form the basis of a policy to minimize its effects.

\section{The aim and objectives of research}

The aim of research is evaluating the effectiveness of the national policy to counter and minimize the effects of the COVID-19 pandemic in terms of individual countries.

Achieving this aim requires fulfilling the following scientific objectives:

1. To analyze the level of impact of the COVID-19 pandemic on the world economy as a whole and individual national economies.

2. To monitor national policies to counter the pandemic and funding volumes for major measures.

3. To evaluate the taken measures in terms of their impact on improving and stabilizing the situation in certain segments of the economy.

4. To develop an expert forecast of the development of individual national economies depending on the effectiveness of measures to minimize the effects of the COVID-19 pandemic.

\section{Research of existing solutions to the problem}

Many publications of scientists are devoted to the problem of the impact of the COVID-19 pandemic on the national and world economies, as well as to the analysis of measures to minimize its effects. Thus, ways to strengthen government fiscal incentives in the process of overcoming the effects of the pandemic in China have been explored in [1]. In [2] the experience of US banks is considered, which is to develop a methodological approach to compiling a matrix of response to COVID-19. This matrix provides a summary of the COVID-19 response measures among the top 10 US retail banks by asset size. These activities include both internal staff support and external assistance to individuals and legal entities, bank customers, and the wider community.

Addressing issues related to the confrontation of the pandemic at the interstate level is raised in [3]. EU leaders have consolidated efforts to resolve differences over joint action against the COVID-19 pandemic. The studies presented in $[4,5]$ reveal the assessment of the scale of the pandemic in Latin America, analyze its impact on the economy and the effectiveness of anti-COVID measures taken by the government. In particular, Cuba's experience with the socialist health care system has proven its effectiveness and ability to counter the pandemic not only at the national level but also to spread it to other countries [6].

The work [7] summarizes the actions of the Turkish competition regulator in response to the COVID-19 pan- demic, providing for the prevention of price discrimination in the field of trade in medicines, medical equipment and essential goods, monopolization and abuse of market position. The economic model for assessing the effects of a pandemic, developed for 33 countries, has shown that the economic recession will be prolonged and no country will be able to avoid its negative impact, regardless of the strategy adopted [8]. According to the developers of this model, these results require a coordinated multinational political response to the pandemic.

Analysis of the impact of the COVID-19 pandemic on the world economy revealed several trends:

- negative dynamics of securities quotations by the world's largest stock exchanges, as a result of which central banks had to reduce interest rates;

- reduce in the number of vacancies and rise in unemployment;

- significant compensation to enterprises in the service sector (tourism, hotel and restaurant industry, transport, especially aviation);

- extremely high incomes and rapid growth of shares of large pharmaceutical multinational corporations [9].

Due to the further implementation of government measures to counter the economic effects of the pandemic, global economic growth is predicted already in 2021

At the same time, the changes in the business environment caused by the pandemic can be assessed in two ways. According to the authors of the study, there are more positive changes for business than negative ones [10].

Further research is required by issues related to evaluating the long-term impact of the pandemic on the world and national economies, scenario modelling of transformation processes in national economic systems in conditions of a pandemic.

Thus, the review of scientific developments in evaluating the impact of the pandemic on the economy made it possible to identify the following areas of research:

- sectoral, aimed at researching the impact of the pandemic on individual industries and segments of the economy (tourism, transport, banking, etc.);

- geographical - evaluating the impact of a pandemic on a particular country or group of countries (EU);

- regulatory - evaluating the impact of regulators on minimizing the effects of a pandemic;

- economic and mathematical modelling - developing a model to evaluate the effects of a pandemic for a group of countries.

At the same time, the issue of evaluating the effectiveness of national policies to minimize the effects and counter the pandemic has not been sufficiently researched and substantiated.

In an emergency of a global nature, government intervention in the process of regulating individual measures to stabilize economic processes has acquired particular importance. The national policy of each country is like a roadmap, determines the way the economy functions in a pandemic.

\section{Methods of research}

The following methods were used in the research: - analysis and synthesis - to analyse the positive and negative changes at the level of national economies as a result of the impact of the COVID-19 pandemic; 
- causal analysis - to identify the results of the impact of a particular policy to counter the pandemic; - comparison - to compare the results of the implementation of the policy to counter the pandemic in specific segments of the economy;

- expert forecasting - to identify major macroeconomic trends in the future;

- generalization - the identification of common features in the studied national policies.

\section{Research results}

The COVID-19 pandemic has created new realities in the functioning of national economies. First of all, due to the partial closure of borders, the volumes of international trade, an international movement of capital and labour decreased. Second, due to the unprecedented spending of governments on the fight against COVID-19, to support national economies, as well as due to global economic recessions in many countries, the volume of general government gross debt has increased significantly.

According to the latest estimates, the unemployment rate has risen from 88 to $115 \mathrm{mln}$ people in 2020 [11].

Besides, the share of the shadow sector of the economy has increased significantly, especially in low-income countries (primarily in the African region) [12].

A survey of business leaders on the perception of the pandemic business was conducted as part of the 20th report on the global competitiveness of the World Economic Forum [11]. Its results showed, firstly, that the pandemic has different effects on competitiveness indicators in developed and developing countries, and secondly, that it has led to both negative and positive shifts in their economies (Tables 1, 2).

As follows from the Table 1, in developed economies there is a decrease in the level of competition for network and professional services, as well as deteriorating cooperation between companies. There were problems finding employees. Many trading companies have transferred their operations to online platforms, thus strengthening their market presence. In developing countries, a survey of business leaders found the following negative trends:

- increasing business costs related to crime and violence; organized crime (these changes reflect the change in the positive trend in 2018-2019, so they should be interpreted as a partial departure from the constant progress in these aspects);

- reduction of the independence of the judiciary;

- further, decline in the level of competition;

- stagnation of trust in politicians, etc.

That is, if in the developed world economic problems dominated, then in the not quite developed - problems of a legal nature, as a reaction to insufficiently stable democratic institutions.

Along with the negative trends in the economic and social spheres, the pandemic pushed business structures to implement managerial and technical innovations. The main positive developments at the state level have been the rapid response of governments to change by formulating and implementing appropriate policies to minimize the effects of the COVID-19 pandemic. Business structures were able to establish cooperation and collaboration based on online platforms (Table 2).

Negative shifts in the economy due to the COVID-19 pandemic in developed and developing countries [11]

Table 1

\begin{tabular}{|c|l|c|c|c|c|c|}
\hline \multirow{2}{*}{ No. } & \multicolumn{3}{|c|}{ Developed countries } & \multicolumn{3}{c|}{ Developing countries } \\
\cline { 2 - 7 } & $\begin{array}{l}\text { Indicator of competitiveness } \\
\text { of the national economy }\end{array}$ & $\begin{array}{c}\text { \% change 2017- } \\
2019 \text { avg vs. 2020 }\end{array}$ & $\begin{array}{c}\text { 2017-2019 aver- } \\
\text { age level (0/100) }\end{array}$ & $\begin{array}{c}\text { Indicator of competitiveness } \\
\text { of the national economy }\end{array}$ & $\begin{array}{c}\text { \% change 2017- } \\
\text { 2019 avg vs. 2020 }\end{array}$ & $\begin{array}{c}\text { 2017-2019 aver- } \\
\text { age level (0/100) }\end{array}$ \\
\hline 1 & $\begin{array}{l}\text { Competition in network } \\
\text { services }\end{array}$ & -2.9 & 67.9 & $\begin{array}{l}\text { Business costs of crime and } \\
\text { violence }\end{array}$ & -2.5 & 52.3 \\
\hline 2 & $\begin{array}{l}\text { Collaboration between } \\
\text { companies }\end{array}$ & -2.6 & 51.9 & Judicial independence & -2.4 & 43.5 \\
\hline 3 & $\begin{array}{l}\text { Eompetition in professional } \\
\text { services }\end{array}$ & -2.3 & 75.0 & Organized crime & -1.2 & 56.5 \\
\hline 4 & Competition in retail services & -1.8 & 78.0 & Extent of market dominance & -0.6 & 43.8 \\
\hline 5 & $\begin{array}{l}\text { Ease of finding skilled } \\
\text { employees }\end{array}$ & -1.5 & 60.0 & Public trust of politicians & -0.4 & 32.0 \\
\hline
\end{tabular}

Note: percent change computed as 2020 score, minus 2017-2019 average score, divided by 2017-2019 average score

Table 2

Positive economic developments due to the COVID-19 pandemic in developed and developing countries [11]

\begin{tabular}{|c|c|c|c|c|c|c|}
\hline \multirow[b]{2}{*}{ No. } & \multicolumn{3}{|c|}{ Developed countries } & \multicolumn{3}{|c|}{ Developing countries } \\
\hline & $\begin{array}{l}\text { Indicator of competitiveness } \\
\text { of the national economy }\end{array}$ & $\begin{array}{l}\text { \% change } 2017- \\
2019 \text { avg vs. } 2020\end{array}$ & $\begin{array}{l}\text { 2017-2019 aver- } \\
\text { age level (0/100) }\end{array}$ & $\begin{array}{l}\text { Indicator of competitiveness } \\
\text { of the national economy }\end{array}$ & $\begin{array}{l}\% \text { change } 2017- \\
2019 \text { avg vs. } 2020\end{array}$ & $\begin{array}{l}\text { 2017-2019 aver- } \\
\text { age level (0/100) }\end{array}$ \\
\hline 1 & $\begin{array}{l}\text { Government's responsiveness } \\
\text { to change }\end{array}$ & 8.2 & 52.1 & $\begin{array}{l}\text { Collaboration within a } \\
\text { company }\end{array}$ & 6.9 & 51.6 \\
\hline 2 & $\begin{array}{l}\text { Collaboration within a com- } \\
\text { pany }\end{array}$ & 4.6 & 65.0 & $\begin{array}{l}\text { Government's responsive- } \\
\text { ness to change }\end{array}$ & 6.8 & 42.3 \\
\hline 3 & Venture capital availability & 4.4 & 47.2 & Efficiency of train services & 5.9 & 34.3 \\
\hline 4 & Social safety net protection & 4.2 & 67.5 & Venture capital availability & 5.9 & 33.6 \\
\hline 5 & Soundness of banks & 4.0 & 73.3 & $\begin{array}{l}\text { Country capacity to attract } \\
\text { talent }\end{array}$ & 5.8 & 40.0 \\
\hline
\end{tabular}


According to experts, digitalization and improvement of digital skills among businesses have become the main positive reaction of business to quarantine measures due to the COVID-19 pandemic [10].

Let's consider in more detail the directions of the economic policy of the states directed on minimization of negative consequences of the entered quarantine.

The analytical sample is represented by Ukraine, the European Union (EU) and countries from different regions severely affected by the COVID-19 pandemic. In East Asia, China is the centre of the pandemic, as well as Iran. In Latin America - Brazil. Among the countries of the African continent, Egypt has suffered the most economically due to a serious blow to the tourism sector. The United Arab Emirates (UAE) has been chosen from the Middle East.

The main directions of the economic policy of the countries selected for analysis in the conditions of COVID-19 are summarized in Table 3. The experience of China, which was the first to take a hit and despite the significant loss of people and resources was able to develop its effective policy of countering the pandemic, is significant. China's fiscal policy alone has allocated 4.8 trillion Yuan, or 747 billion USD. This is $4.7 \%$ of the country's GDP. Because the funds were directed to lending to small and medium enterprises ( $8 \%$ of the total amount of fiscal measures), to the banking sector (11.5\%), support of the stock exchange $(37.5 \%)$ to ensure uninterrupted supply of medical equipment, and also reducing tariffs and taxes (19\%), the government managed to achieve economic growth. In 2020, China's GDP grew from 10.29 thousand USD up to 10.58 thousand USD per capita, i. e. by $2.8 \%[17,19]$. If to consider the quarterly dynamics of GDP (Fig. 1), then in China the peak of the fall fell on the fourth quarter of 2019. The beginning of the pandemic, and with it the unpreparedness and some time for decision-making allowed GDP to go down sharply. As measures have been taken to minimize the effects of the pandemic, GDP has resumed growth.

Directions of the state policy of minimization of consequences pandemic COVID-19 of the individual countries

Table 3

\begin{tabular}{|c|c|c|c|c|}
\hline No. & Country & Measures to minimize the effects of the pandemic & The amount of their funding, USD & The direction of national policy \\
\hline \multirow{5}{*}{1} & \multirow{5}{*}{ China } & Lending to small and medium businesses & 62 bln & Credit \\
\hline & & Reduction of required reserves & 85.2 bln & \multirow{2}{*}{ Monetary } \\
\hline & & Infusion in the form of open market operations & 263.5 bln & \\
\hline & & Fiscal measures to combat COVID-19 & 747 bln & Fiscal \\
\hline & & Reduction of duties and taxes & 139.5 bln & Tax \\
\hline \multirow{5}{*}{2} & \multirow{5}{*}{ Iran } & Lending to small and medium businesses & $4.4 \%$ GDP & Credit \\
\hline & & Infusion into the foreign exchange market & $1.5 \mathrm{bln}$ & Monetary \\
\hline & & Increasing budget expenditures on health care & $2 \%$ GDP & Budget \\
\hline & & Moratorium on taxes & $6 \%$ GDP & $\operatorname{Tax}$ \\
\hline & & Unemployment insurance & $0.3 \%$ GDP & Insurance \\
\hline \multirow{4}{*}{3} & \multirow{4}{*}{ UAE } & Reduction of required reserves & 70 bln & Monetary \\
\hline & & Fiscal measures to combat COVID-19 & $1.85 \mathrm{bln}$ & Fiscal \\
\hline & & Tax benefits & 0.4 bln & $\operatorname{Tax}$ \\
\hline & & Private sector support & 4.4 bln & Budget \\
\hline \multirow{4}{*}{4} & \multirow{4}{*}{ Ukraine } & Lending to small and medium businesses & $625 \mathrm{mln}$ & Credit \\
\hline & & Increasing budget expenditures on health care & 2.9 bln & \multirow{2}{*}{ Budget } \\
\hline & & Development of medical infrastructure & $158 \mathrm{mln}$ & \\
\hline & & Payment of unemployment benefits and dismissal & $384 \mathrm{mln}$ & Sacial, budget \\
\hline \multirow{7}{*}{5} & \multirow{7}{*}{ EU } & Lending to small and medium businesses & $1.2 \operatorname{tn}$ & Credit \\
\hline & & Additional purchase of securities by the central bank & 900 bln & \multirow{2}{*}{ Monetary } \\
\hline & & Increasing the liquidity of the banking sector & 144 bln & \\
\hline & & Increasing budget expenditures on health care & 288 bln & \multirow{2}{*}{ Budget } \\
\hline & & Establishment of the COVID-19 Pandemic Recovery Fund & 900 bln & \\
\hline & & $\begin{array}{l}\text { Support for public investment for hospitals, small and medium } \\
\text { enterprises, labour markets }\end{array}$ & 44.4 bln & Investment \\
\hline & & Refusal of significant reductions and protection of jobs & 120 bln & Social, budget \\
\hline \multirow{3}{*}{6} & \multirow{3}{*}{ Brazil } & Lending to small and medium businesses & 12 bln & Credit \\
\hline & & Cash payments to households & 16.7 bln & Sacial, budget \\
\hline & & Increasing budget expenditures on health care & $4.5 \mathrm{bln}$ & Budget \\
\hline \multirow{4}{*}{7} & \multirow{4}{*}{ Egypt } & Lending to small and medium businesses & $127.5 \mathrm{mln}$ & Credit \\
\hline & & Increasing budget expenditures on health care & $318.8 \mathrm{mln}$ & Budget \\
\hline & & Fiscal measures to combat COVID-19 & $390.8 \mathrm{mln}$ & Fiscal \\
\hline & & Targeted support for the tourism sector & $3.2 \mathrm{bln}$ & Structural and sectoral \\
\hline
\end{tabular}

Note: built on data $[1,3-5,13-18]$ 
Given the fact that the GDP of most countries declined in 2020, it is possible to predict that in China, due to economic growth in 2020, GDP growth will continue to grow in 2021.

During the pandemic period (2020), the share of China's general government gross debt in GDP increased from $52.6 \%$ to $61.7 \%$ [20]. Given the stabilization of GDP growth and the ambitious measures taken by the Chinese government to support various segments of the economy, it is possible to predict a further increase in the level of general government gross debt to GDP to 70-73\%.

The effectiveness of the policy of countering the pandemic in Iran is of particular interest for analysis, as this country has long been under economic sanctions. Iran is also one of the countries most affected by COVID-19 in terms of the number of people infected in Asia. However, if to analyze the dynamics of GDP for the period 2019-2020, it can be noted that its significant decline took place before the pandemic. Since in its national policy, Iran followed the Chinese version, focusing fiscal measures on lending to small and medium-sized businesses, and only this field was allocated $4.4 \%$ of GDP (compared to $0.4 \%$ of GDP in China), then in the first quarter of 2020 a slowdown in the rate of decline in GDP can be observed (Fig. 1). Iran has also allocated 1.5 billion USD to support the foreign exchange market, due to which it was possible to ensure stable exchange rate dynamics at the level of 42 Iranian rials per dollar. Overall, most of the funds were allocated to ensure a tax moratorium to reduce the burden on enterprises during the crisis. Due to this, in 2020 the GDP per capita grew by $3.6 \%$, which is more than in China, so in Iran in the future is predicted to increase GDP growth [17, 19].

Large-scale monetary policy in China and Iran has helped hold back rising inflation caused by the COVID-19 pandemic. In China, it remained at $2.9 \%$, so it is possible to predict that inflation in China in 2021 will not exceed $3 \%$ and should decrease. As for Iran, in 2019 it had a fairly high inflation rate $(41 \%)$. Despite the global challenge of the pandemic in 2020 , the government has managed to reduce inflation to $30.5 \%$ (by $25.6 \%$ ), so let's predict that in 2021 inflation in Iran will be in the region of 20 to $30 \%$ [21].

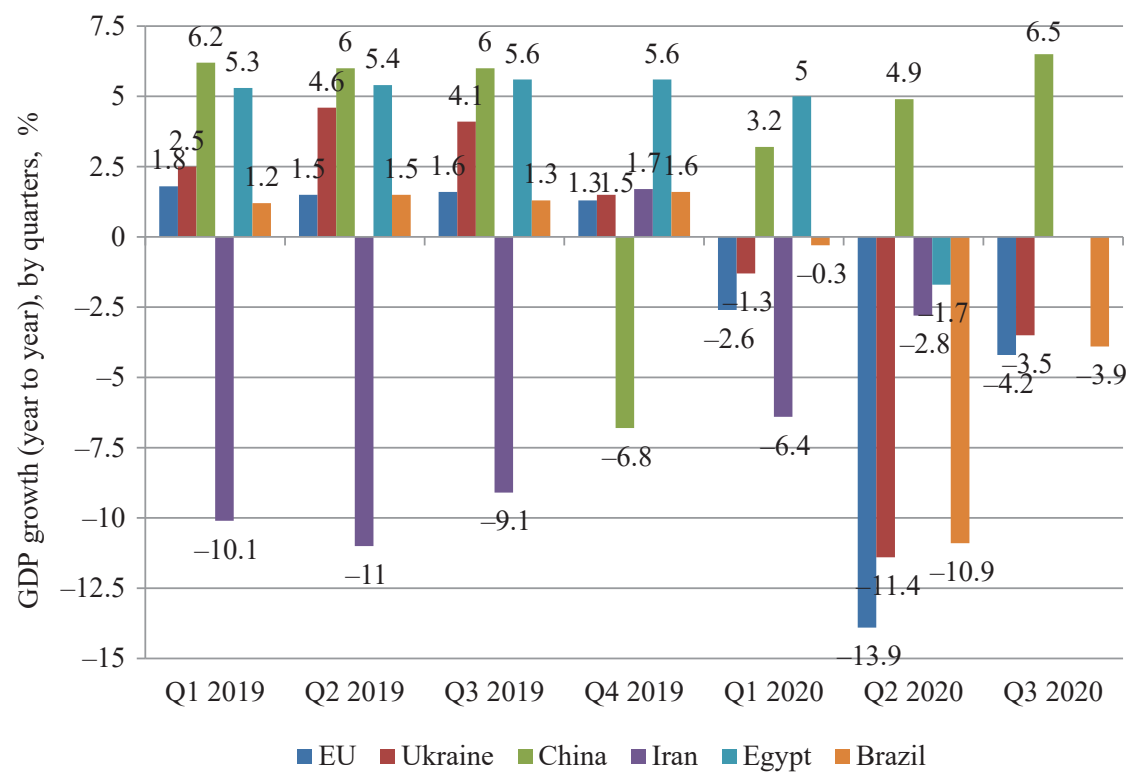

Fig. 1. GDP growth rate of the European Union, Ukraine, China, Iran, Egypt, Brazil. Note: built on data [19]
Although fiscal and monetary policies in China and Iran have proved effective, countries have not been able to avoid rising unemployment in 2020: in China from 3.6 to $3.8 \%$, and in Iran from 10.7 to $12.2 \%$ compared to 2019 [22]. This is due to the lack of effectiveness of social and insurance policies. So, Iran in 2020 allocated only $0.3 \%$ of GDP for unemployment insurance, therefore, there is a serious increase in unemployment by 1.5 points. In China, the cost of social unemployment insurance in 2020 was much higher and amounted to $2 \%$ of GDP, so that unemployment increased by only 0.2 points [17]

Thus, the forecast of the unemployment rate for Iran is negative, if the costs of a social insurance policy are not increased, as for China, let's predict that the unemployment rate should decrease in 2021 , as the state began to allocate significant amounts of money for its insurance. In Iran, the share of general government gross debt to GDP in 2020 has not changed (increased by 1 point) from 44.7 to $45.4 \%$ [20], so it is possible to predict that in 2021 it will not exceed $46 \%$.

However, among these Asian countries are those whose national policies to minimize the effects of COVID-19 are not effective enough. This is, for example, the UAE. In 2020, the volume of GDP per capita in this country decreased to $18.5 \%$ from 39.18 to 31.95 thousand USD [23]. Tourism, aviation and education have been suffered the most. If to compare the policy of the UAE with the policy of the countries that are more successful in minimizing the effects of the pandemic, it can be noted that although a lot of funds has been allocated for fiscal incentives, it is still not enough $-2.8 \%$ of GDP ( 8.7 billion USD). By comparison, Iran, which is under economic sanctions, has allocated $4.4 \%$ of GDP to business lending alone. 0.4 billion dollars has been allocated for tax benefits $(6 \%$ of GDP in Iran). However, in the UAE, deflation remains at $-1.5 \%(-1.9 \%$ in 2019$)$, caused by falling real estate prices, which began in 2016. The pandemic further squeezed demand for real estate and led to another decline in prices [21]. It is possible to predict a further decline in deflation in 2021 due to a sharp drop in GDP.

At the same time, it is possible to expect economic growth in the UAE in 2021, due to the large-scale monetary policy of the state. The Central Bank of the UAE has announced a package of measures of 70 billion dollars (20\% of GDP of the UAE), aimed at reducing the regulatory reserves of banks, the liberalization of the banking sector. Simplification of banking operations, deferral of loans, preferential lending for businesses is provided [17]. However, a significant allocation of funds for monetary policy will lead to further growth of general government gross debt: in 2020, its share in GDP increased from 27.3 to $36.9 \%$, and it is possible to predict further growth in 2021 to at least $40 \%$.

Among countries listed in the Table 3 only Egypt managed to achieve economic growth in 2020. Thus, GDP per capita increased from 3.04 to 3.42 thousand USD or $12.5 \%$ [19]. 
The most developed in Egypt is the tourism sector. Therefore, a significant part of the funds was allocated to support it under quarantine conditions, namely $12 \%$ of the country's total GDP, due to which it was possible to avoid a fall in the industry and reorient to quarantine conditions. Besides, the Egyptian authorities launched a wide social campaign: they increased pensions by $14 \%, 2.4 \%$ of GDP was directed to concessional consumer lending. Social programs have been significantly expanded, especially for workers in the tourism sector. Egypt also has a broad national policy focus on COVID-19. Besides fiscal, structural and social policies, monetary policy (a significant amount of guarantees of the Central Bank - $1.8 \%$ of GDP, simplification of banking operations) and tax policy (introduction of holidays for most taxes) are also implemented [17]. Health care is also heavily funded, so that in Egypt over the past 5 months, the number recovered significantly exceeds the number of patients [24].

In 2021, it is possible to expect a continued trend of increasing GDP per capita growth rates in Egypt. The pace itself will depend on the opening speed of other tourist destinations. If the trend does not change, and Egypt remains open to tourist flows, then GDP growth is expected at the level of $9-10 \%$. And this is a very high level for developing countries, even in the pre-pandemic period.

The inflation rate in Egypt in 2020 decreased from 13.9 to $5.7 \%$ [21]. It is possible to predict in 2021 the stabilization of inflation at $5 \%$. Egypt is one of the few countries where the unemployment rate fell in 2020: from 8.6 to $8.3 \%$ compared to the previous year [22]. As for the general government gross debt, in Egypt, it grew slightly from 83.8 to $86.6 \%$ about GDP, which also illustrates a fairly effective budget policy. It is possible to predict in 2021 the inflation rate will not exceed $8 \%$ and the level of general government gross debt will be in the range of $80-90 \%$. That is, no special changes in these directions are envisaged [20].

Brazil was subjected to the largest economic recession among the selected countries: its GDP per capita fell in 2020 from 8.75 to 6.45 thousand USD (by $26.3 \%$ ) [19]. The reason for the economic recession is that the Brazilian authorities have significantly underestimated the scale of the spread of COVID-19. Due to the lateness of preventive measures, Brazil is one of the most affected countries, both in terms of the number of COVID-19 patients and economically. Inconsistent government policy led to a significant increase in the primary budget deficit to $8.3 \%$ of GDP $[16,17]$.

Although the government's fiscal measures amounted to $12 \%$ of GDP and were implemented in different directions of national policy (social, fiscal, monetary), however, it was ineffective. Also, the state should pay attention to unemployment insurance and allocate more funds to support vulnerable industries, since much more funds were allocated to households than to businesses [17]. In the future, a further drop in Brazilian GDP can be expected, although the rate of such a drop will slow down somewhat.

The share of general government gross debt in Brazil's GDP increased rapidly in 2020 from 89.5 to $101.4 \%$ [20]. The combination with the high level of the primary budget deficit allows to forecast further growth of Brazil's general government gross debt to $110 \%$ in 2021 .

Due to the lack of well-functioning insurance policy on unemployment, namely the introduction of measures only partial compensation to employees, it has risen from 11.9 to $13.4 \%$ in the country [22]. Since the state allocates more funding in social policy to pensioners and low-income people than to business, it is possible to predict a further increase in unemployment to $15 \%$ in 2021.

However, on the positive side, the clear social focus of measures in Brazil help avoided the rise in inflation in the country and led to a decrease in its level from 3.7 to $2.7 \%$. In 2021 , it is possible to expect an increase in inflation due to the possible emission of money to cover the budget deficit and general government gross debt.

The European Commission has developed a comprehensive policy to counter and minimize the consequences of the pandemic, covering financial assistance to small and medium-sized enterprises, supporting the banking system and the health sector, etc. (Table 1). The SURE (Support Mitigating Unemployment Risks in Emergency) program was developed to reduce the risks of unemployment in emergency.

The EU economy has also been affected by negative trends. There is a decline in GDP growth rates, which reached its apogee in the second quarter of 2020. At the same time, given the sufficient safety margin of the economy under quarantine conditions, the EU overcame the negative trend and reduced the rate of decline.

In July 2020, representatives of EU member states decided to allocate an additional 750 billion EUR for economic recovery after the pandemic. It also provides a long-term EU budget of 1,074.3 billion EUR in 2021-2027.

Together with the 540 billion EUR allocated to three social protection systems (for employees, companies and member states), the total package of EU economic recovery will be 2,364.3 billion EUR [25].

If in 2019 the GDP growth rate of Ukraine was $3.2 \%$, then during the three quarters of 2020 it was negative, with the lowest value in the 2nd quarter $(-11.4 \%)[19,21]$. The sharp decline in real GDP in Ukraine during this period indicates the ineffectiveness of initial measures to minimize the effects of quarantine and the unwillingness of the economy to balance quarantine measures.

In the third quarter of 2020, Ukraine managed to overcome the negative growth of real GDP, but this is not enough for its further growth, as limited financial resources do not allow supporting fiscal incentives. However, the annual growth of consumer prices was insignificant.

\section{SWOT-analysis of research results}

Strengths. The strengths of the research are that the effectiveness of the policy to counter and minimize the effects of the COVID-19 pandemic of individual countries is monitored and specified. Compared to other studies assessing the impact of the COVID-19 pandemic on national economies, the emphasis is on the effectiveness of policies to minimize the effects of the pandemic. A comparative analysis of the implemented measures and the main macroeconomic results allows to evaluate their effectiveness and to provide an expert forecast for further trends in economic development.

Weaknesses. This methodological approach is limited to the analysis of macroeconomic indicators and does not take into account structural changes in certain segments of the economy.

Opportunities. The developed methodological approach can be supplemented with data from global rankings depending on the purpose of the research (for example, the Global Competitiveness Index, Global Innovation Index, Ease of Doing Business, etc.). Based on mentioned policies, it is possible to identify and structure countries' strategies to counter and minimize the effects of the COVID-19 pandemic. 
Threats. Data for analysis are not always available and comparable. In particular, this applies to countries with closed economies, countries under economic sanctions and underdeveloped countries with imperfect state statistics.

\section{Conclusions}

1. The level of impact of the COVID-19 pandemic on the world economy and the economies of individual countries is analyzed and the differences between developed and developing countries are revealed. While developed countries have problems with competitiveness and cooperation, developing countries suffer from rising crime and imperfect justice.

2. Monitoring of national policies to minimize the effects of the pandemic of individual countries has identified common areas of such policies: tax benefits, social insurance in case of unemployment and stabilization of the banking system.

3. Evaluating measures to minimize the effects of a pandemic through the prism of their impact on key macroeconomic indicators have revealed successful examples based on significant support for small and medium-sized businesses. Exactly business structures produce GDP and fill the state budget, balancing macroeconomic proportions.

4. Expert forecasting of certain parameters of development of the analyzed countries allowed formulating a hypothesis about some patterns that will take place in 2021 and are the result of implemented policies to minimize the effects of the pandemic:

- strong economies with a significant margin of safety and the economies of developing countries, which have shifted the emphasis to supporting business structures, will be able to slow the decline in GDP and inflation, and gradually stabilize the lost economic potential;

- countries that have postponed measures to counter the pandemic, and carried out sporadic measures that were not systemic in nature, in 2021 will be forced to seek resources to overcome inflation in the economy and falling GDP.

\section{References}

1. Yao, K. (2020). China's coronavirus crisis fans calls for fasttracked stimulus. Reuters. Available at: https://www.reuters.com/ article/us-health-coronavirus-china-stimulus/chinas-coronavirus-crisis-fans-calls-for-fast-tracked-stimulus-idUSKCN2240QJ

2. Magana, A., Green, R. (2020). Coronavirus response matrix: these are the steps US banks are taking to confront the coronavirus pandemic. Business Insider. Available at: https://www.businessinsider.com/steps-us-banks-are-taking-to-confront-coronaviruspandemic-2020-4

3. Chapman, C. (2020). A Response to the Coronavirus Pandemic Has Stumped EU Leaders. Australian Institute of International Affairs. Available at: https://www.internationalaffairs.org.au/ australianoutlook/20665

4. Altman, D., Valarezo, J. C. (2020). Deaths and desperation mount in Ecuador, epicenter of coronavirus pandemic in Latin America. The Conversation. Available at: https://theconversation.com/deaths-and-desperation-mount-in-ecuador-epicenterof-coronavirus-pandemic-in-latin-america-137015

5. Burki, T. (2020). COVID-19 in Latin America. The Lancet In fectious Diseases, 20 (5), 547-548. doi: http://doi.org/10.1016/ s1473-3099(20)30303-0

6. Vivanco, P. (2020). Cuba is Ready to Aid the U.S. in its Fight Against COVID-19. The Progressive. Available at: https://progressive.org/dispatches/cuba-ready-aid-us-in-fight-against-covidvivanco-200430

7. Buğra Aydin, A., Özer, N. (2020). Impacts Of COVID-19 On Competition: How Are Competition Authorities Responding To The Pandemic? Mondaq. Available at: https://www.mondaq.com/turkey/ antitrust-eu-competition-/942900/impacts-of-covid-19-on-competition-how-are-competition-authorities-responding-to-the-pandemic
8. Chudik, A., Mohaddes, K., Hashem Pesaran, M., Raissi, M. Rebucci, A. (2020). Economic consequences of Covid-19. A counterfactual multi-country analysis. VoxEU. Available at: https://voxeu.org/article/economic-consequences-covid-19-multicountry-analysis

9. Jones, L., Palumbo, D., Brown, D. (2021). Coronavirus: How the pandemic has changed the world economy. BBC Neres. Available at: https://www.bbc.com/news/business-51706225

10. Ang, C. (2020). The Economic Impact of COVID-19, According to Business Leaders. Visual Capitalist. Available at: https:// www.visualcapitalist.com/economic-impact-covid-19/

11. Klaus Schwab, K., Zahidi, S. (2020). The Global Competitiveness Report Special Edition 2020: How Countries are Performing on the Road to Recovery. World Economic Forum. Geneva, 94. Available at: http://www3.weforum.org/docs/WEF_TheGlobalCompetitivenessReport2020.pdf

12. Vozdeistvie pandemii COVID-19 na Afriku (2020). Orgnanizatsiia Obedinennykh Natsii. Available at: https://www.un.org/ sites/un2.un.org/files/africa covid brief russian.pdf

13. Subran, L., Garatti, A., Boata, A., Barthalon, E. (2020). COVID-19 Quarantined economics. Euler Hermes. Available at: https://www. eulerhermes.com/en global/news-insights/economic-insights/ covid-19-quarantined-economics.html

14. United States of America. Government and institution measures in response to COVID-19 (2020). KPMG. Available at: https://home $\mathrm{kpmg} / \mathrm{xx} / \mathrm{en} / \mathrm{home} /$ insights/2020/04/united-states-of-americagovernment-and-institution-measures-in-response-to-covid.htm

15. Timmers, B., TenBruggencate, M. (2020). Canada's Task to Leave No One Behind During COVID-19 Pandemic. International Institute for Sustainable Development. Available at: https://www.iisd.org/articles/canada-covid-leave-no-one-behind

16. Covid-19 in Latin America: Brazil Hardest Hit as Region Braces for Peak Pandemic (2020). Leaders League. Available at: https://www.leadersleague.com/en/news/covid-19-in-latinamerica-brazil-hardest-hit-as-region-braces-for-peak-pandemic

17. Policy Responses to Covid-19 (2021). International Monetary Fund. Available at: https://www.imf.org/en/Topics/imf-andcovid19/Policy-Responses-to-COVID-19

18. Maliszewska, M., Mattoo, A., van der Mensbrugghe, D. (2020). The Potential Impact of COVID-19 on GDP and Trade: A Preliminary Assessment. Policy Research Working Paper, No. 9211. Washington: World Bank. Available at: http://hdl.handle.net/10986/33605

19. Real GDP growth. Annual percent change (2021). International Monetary Fund Data Mapper. Available at: https://www.imf.org/ external/datamapper/NGDP_RPCH@WEO/OEMDC/ADVEC/ WEOWORLD

20. General government gross debt. Percent of GDP (2021). International Monetary Fund Data Mapper. Available at: https:// www.imf.org/external/datamapper/GGXWDG NGDP@WEO/ OEMDC/ADVEC/WEOWORLD

21. Inflation rate, average consumer prices. Annual percent change (2021). International Monetary Fund Data Mapper. Available at https://www.imf.org/external/datamapper/PCPIPCH@WEO/ OEMDC/ADVEC/WEOWORLD

22. Unemployment rate. Percent (2021). International Monetary Fund Data Mapper. Available at: https://www.imf.org/external/ datamapper/LUR@WEO/OEMDC/ADVEC/WEOWORLD

23. GDP per capita, current prices. U.S. dollars per capita (2021) International Monetary Fund Data Mapper. Available at: https://www.imf.org/external/datamapper/NGDPDPC@WEO/ OEMDC/ADVEC/WEOWORLD

24. Koronavirus v Yehypti (2021). Ministerstoo finansiv Ukrainy. Available at: https://index.minfin.com.ua/ua/reference/coronavirus/geography/egypt/

25. COVID-19: The EU's response to the economic fallout (2021). European Council of the European Union. Available at: https://www. consilium.europa.eu/en/policies/coronavirus/covid-19-economy/

Oksana Okhrimenko, Doctor of Economic Sciences, Professor, Department of International Economy, National Technical University of Ukraine «Igor Sikorsky Kyiv Polytechnic Institute», Kyiv, Ukraine, e-mail: o.okhrimenko@kpi.ua, ORCID: http://orcid.org/ 0000-0001-7361-3340

Oleksii Zrobok, Department of International Economy, National Technical University of Ukraine «Igor Sikorsky Kyiv Polytechnic Institute», Kyiv, Ukraine, e-mail: zrobok.alex@gmail.com, ORCID: http://orcid.org/0000-0002-8595-8546 